\section{Aquatic-dwelling Weevils}

In Nature of September 6 there is a note (p. 472) on Dr. Nelson Annandale's papers on the fresh-water fauna of India, ending with the words " an aquatic weevil, which, so far at any rate as habits are concerned, is altogether unique." If this sentence is intended to mean that water-dwelling weevils were previously unknown it is incorrect.

Mr. J. H. Keys and myself took specimens of the weevil Eubrychius velatus, Beck, from a pond near Plymouth in September, 1905, which were as thoroughly aquatic as any of the typical water-beetles (e.g. Dytiscidæ), most of their time being spent in crawling under water on the leaves and stems of Myriophyllum. Fowler has an interesting note on this species, to the same effect, in his "Coleoptera of the British Islands," vol. v., p. 373.

Mr. Keys also states that Tanysphyrus lemnae, F., and the various species of Bagous are all more or less aquatic. E. E. LowE.

Museum and Art Gallery, Beaumont Park, Plymouth, September I I.

\section{Remarkable Rainbow Phenomena.}

The letter of Mr. M. Spence in Nature of September 20, describing a bifurcated rainbow, reminds me of a similar phenomenon which I saw some time during the winter of $1897-8$. On that occasion the phenomenon was not so complete as that described by $\mathrm{Mr}$. Spence, only the lefthand portion of the bow being visible. The arch rose from the horizon as a single column to a height of about ten degrees, and then bifurcated into two distinct branches, which, however, did not extend far from the join.

As I was playing in a football match at the time it was impossible to study the effect at all closely; but, so far as I remember, the lower branch sprang out of the main regular bow, making with it an angle larger than that described by Mr. Spence. My incomplete observations were not alone of much value, but in confirmation of $\mathrm{Mr}$. Spence's fuller description they may be worth recording now.

Manchester University.

Is it not the case that the second rainbow seen by your correspondent (p. 5i6) was caused by the reflection of the sun in the sea? If this were so, naturally persons some miles west of Deerness, or inland, would not have seen it. I once saw the appearance of double rainbows beautifully manifested in Ranenfjord, on the coast of Norway, and the explanation which I have given is that which found most favour with the passengers on our steamer.

Banwell Vicarage, September 2 I.

C. S. TAYLOR.

\section{SOME SCIENTIFIC CENTRES.}

\section{IX.-The Metallurgical Department of the} ShefField University.

NEARLY fifty years ago Sir John Brown; the famous engineer and steel manufacturer, with Dr. H. C. Sorby, the father of the introduction of the microscope for the examination of thin sections of rocks and of polished or polished and etched surfaces of iron and steel, attempted to establish in Sheffield a school of practical science; but as yet Britain held undisputed sway in the world of engineering and of metals; and the help of science, proffered by these far-seeing men, although just as desirable then as now, was rejected by such easy victors in the wars of commerce. The sum of $200 l$. was spent in advertising, with the result that only one student entered. Several years' perseverance never produced more than five students, so far as Dr. Sorby's memory serves him. Sixteen years later the added personal influence of such men as Mr. Mark Firth, Sir Frederick Mappin, Sir Henry Stephenson, and Mr. J. F. Moss failed to find a response, and although in
I879 Mr. Mark Firth founded Firth College to facilitate university extension work, it was not until $188_{3}$ that another special meeting was held, at which Dr. Sorby used the following pregnant words : "I do not see why we should not make the teaching of metallurgy a speciality of the town, nor why we should not make Sheffield the centre of metallurgical instruction."

In 1885 the Sheffield Technical School was fairly launched in a separate building, but as a department of Firth College, with chairs of engineering and of metallurgy both held by the late Prof. W. H. Greenwood. Until 1889 the department of metallurgy was in connection with the Science and Art Department, and its work consisted of courses of lectures on fuel, refractory materials, iron, steel, and general metals, with assaying and experiments in a laboratory fitted with analytical benches, wind and muffle furnaces similar to those in the Royal School of Mines of that date. In 1889, Prof. Greenwood having resigned his chairs to undertake the management of the Birmingham Small Arms Factory, John Oliver Arnold was appointed to the chair of metallurgy which he holds to-day. He began at once to inaugurate revolutionary changes, the fundamental aims of which seemed to be : (I) to increase the science of the metals themselves, the art being then in great preponderance; (2) as the industries of the district were mainly of iron and steel, to pay special attention to these, assured that science could be as truly served and minds as fruitfully trained on metals of immediate interest to the district as on the wider range; and (3) to keep the ideal ahead of having available on a small scale, but by a manufacturing method as distinct from a laboratory method, examples of as many types of metallurgical processes as possible, so that the students might examine the whole course of each process from beginning to end in the comparative calm of an educational establishment. A start was made by erecting a two-hole crucible steel-melting furnace fully equipped as a small works, and differing only from the large works in the city in that theirs would consist of so many dozens or hundreds of holes of the same size. The effect on the attendance was electrical, and the available laboratory accommodation was at once completely filled. A difficulty here arose in that the Science and Art Department objected to the course, but a very simple solution was found in cutting the laboratory adrift from Government control, the public men supporting it guaranteeing against any resulting financial difficulty. It ought in justice to be said that in those days the department did sounder work for pure science than it seems to be the present fashion to acknowledge, although its influence on metallurgy in Sheffield was not good.

The complete success of this first part enabled Prof. Arnold to induce the members of the governing committee to commence the more ambitious part of his scheme, though with some misgivings, and during the session $1890-9$ I the students had the rare privilege of following the erection of, as well as working, plant consisting of a $25 \mathrm{cwt}$. acid Siemens furnace, with gas producers and all necessary hydraulic power for lifts, a No. $\frac{1}{2}$ Stewart rapid cupola, foundry with drying stove for sand and "compo" moulds, and a falling weight test apparatus. As showing the curious features which sometimes govern a problem, although the No. $\frac{1}{2}$ cupola worked well it had soon to be replaced by a No. I, as when the lining began to wear it was only with the utmost difficulty that even a temporary assistant of the staff could be obtained sufficiently attenuated to be able to effect the necessary repairs, and at any time inspection of the lining was somewhat of an acrobatic performance. A 50-ton Wicksteed mechanical testing machine for tensile, trans-

No. I926. VOL. 74] 